\title{
Розвиток хвороб системи кровообігу, цукрового діабету та ожиріння в учасників ліквідації наслідків аварії на ЧАЕС у 30-річний післяаварійний період
}

Проведено визначення динаміки розвитку гіпертонічної хвороби (ГХ), ішемічної хвороби серця (ІХС), цукрового діабету (ЦД) 2-го типу та ожиріння в учасників ліквідації наслідків аварії на ЧАЕС (УЛНА) впродовж ЗО-річного періоду спостереження. Встановлено, що після участі в аварійних роботах ГХ, ІХС, ЦД 2-го типу та ожиріння в когорті УЛНА розвивались у більш ранній термін і в молодшому віці порівняно з неопроміненими особами. Переважна кількість УЛНА захворіли на ГХ в перші 10 років, осіб контрольної групи(КГ) - під час 2-го та 3-го десятиріччя після аварії. В усіх УЛНА ознаки ІХС виявлені в перші 20 років, в осіб КГ- в 3-му десятиріччі періоду спостереження. У 93,9\% УЛНА розвиток ГХ достовірно випереджав клінічний дебют ЦД на 25, 7 року, а у 66, 7\% розвиток ІХС - на 19,4 року. У 92,0\% осіб КГ ця різниця становила 19,5 року, в 76,0\% - 15,5 року відповідно. ГХ вірогідно підвищувала ризик розвитку ЦД 2-го типу як в УЛНА, так і у КГ, тоді як IXС не зумовлювала такого впливу. Більше половини УЛнА та осіб КГ мали надмірну масу тіла чи ожиріння, коли в них розвинулися ГХ та IXС. Участь уліквідації наслідків аварії на ЧАЕС в поєднанні із впливом іонізуючого випромінювання можна вважати вірогідним фактором ризику ГХ, IXС і ЦД 2-го типу.

Ключові слова: учасники ліквідації наслідків аварії на ЧАЕС, гіпертонічна хвороба, ішемічна хвороба серця, цукровий діабет.

\section{Вступ}

Вплив зовнішніх та внутрішніх факторів ризику на організм людини призводить до формування різних хвороб, перебіг яких на початковому етапі розвитку відбувається за єдиним патогенетичним механізмом і які одержали назву коморбідних захворювань (КЗ). Чим старша людина, тим вища ймовірність появи в неї більшої кількості КЗ, оскільки із природним старінням знижуються функціонально-компенсаторні можливості організму. Серцевосудинна система (ССС) - одна з найбільш схильних до ураження, про що свідчить висока поширеність серцево-судинних захворювань (СС3) та їх перше місце як причини смертності населення високорозвинених країн Європи (Wilkins E. et al., 2017). Крім того, вони мають патофізіологічний зв'язок із різними КЗ, що спричиняють прогресивне зростання частки пацієнтів із комбінацією декількох захворювань та/чи синдромів, основна складова яких кардіальна патологія (Митьковская Н.П., 2016).

Цукровий діабет (ЦД) та ожиріння - найпоширеніші терапевтичні патології, що супроводжують такі СС3, як гіпертонічна хвороба (ГX) та ішемічна хвороба серця (IXC), а також значно підвищують серцево-судинний ризик та погіршують прогноз щодо фатальних і нефатальних серцево-судинних ускладнень (Кваша Е.A., 2005; Adams K.F. et al., 2006; Дементьев В.Е. и соавт., 2010; Аметов А.С., Лысенко М.А., 2011; Галяви Р.А. и соавт., 2014; Чесникова А.И. и соавт., 2016; Старченко Т.Г. та співавт., 2018).

Більшість робіт присвячено вивченню взаємного обтяження КЗ, але не черговості ї̈ виникнення у пацієнта, особливо в осіб, які зазнали впливу рідких факторів зовнішнього середовища, а саме іонізуючого випромінювання. Показано, що вперше виявлений ЦД 2-го типу виникав у пацієнтів, які вже хворіли на СС3. Так, артеріальну гіпертензію (АГ) виявлено у 65\%, інфаркт міокарда (IM)/зміни на електрокардіограмі (ЕКГ) - у 34\%, інсульт у $38 \%$, захворювання периферичних судин (макроангіопатію) у 46\% пацієнтів (Древаль А.В., 2018).

Мета - визначення динаміки розвитку ГX, IXC, ЦД та ожиріння в учасників ліквідації наслідків аварії на ЧАЕС (далі - УЛНА) впродовж 30-річного періоду спостереження.

\section{Об'єкт і методи дослідження}

У дослідження увійшли 144 УЛНА 1986 р. та 105 осіб контрольної групи (КГ). Усі обстежені, включаючи пацієнтів із КГ, були чоло- віками, міськими мешканцями, які до аварії не мали ознак серцевосудинної, неврологічної, легеневої чи ендокринної патології. Для обох груп дата аварії була точкою відліку розвитку ССЗ. Вікова, дозиметрична та клінічна характеристика учасників на момент останнього обстеження наведена у табл. 1. Пацієнтів із тяжкою легеневою, шлунково-кишковою чи іншою патологією, яка розвинулась у процесі спостереження, не включали.

Група УЛНА практично не відрізнялася від КГ ані за віком на момент аварії, ані за клінічними показниками (відносною кількістю пацієнтів із ГХ та IXC, включаючи постінфарктний кардіосклероз, частотою $\mathrm{CH}$, порушень серцевого ритму і провідності, наявністю супутнього ЦД). У КГ частіше діагностували стенокардію II ФК, в УЛНА - III ФК. Серед останніх дещо більшою була частка пацієнтів, які перенесли гостре порушення мозкового кровообігу. У процесі тривалого спостереження в УЛНА не виявлено залежності розвитку/прогресування кардіальної патології,

Таблиця 1. Вікова, дозиметрична та клінічна характеристика обстежених

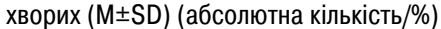

\begin{tabular}{|c|c|c|c|}
\hline Показник & $\begin{array}{c}\text { УЛНА } \\
(n=144)\end{array}$ & $\begin{array}{c}\mathrm{K} \Gamma \\
(n=105)\end{array}$ & p \\
\hline Середній вік на момент аварії, років & $36,3 \pm 10,0$ & $37,7 \pm 9,0$ & $>0,05$ \\
\hline Середній вік на момент останнього обстеження, років & $59,8 \pm 11,8$ & $65,9 \pm 9,0$ & $<0,001$ \\
\hline Поглинута доза опромінення, сГр (n=75) & $142 \pm 154$ & - & - \\
\hline$\Gamma X$ & $123 / 85,4$ & $88 / 83,8$ & $>0,05$ \\
\hline IXC & $116 / 80,6$ & $91 / 86,7$ & $>0,05$ \\
\hline ГX та IXC & $102 / 70,8$ & $75 / 71,4$ & $>0,05$ \\
\hline IXC, стабільна стенокардія: & $60 / 41,7$ & $52 / 49,5$ & $>0,05$ \\
\hline • І функціональний клас (ФК) & $4 / 6,7$ & $2 / 3,8$ & $>0,05$ \\
\hline - \| ФK & $38 / 63,3$ & $40 / 76,9$ & $<0,05$ \\
\hline • III ФK & $18 / 30,0$ & $10 / 19,2$ & $<0,05$ \\
\hline Постінфарктний кардіосклероз & $21 / 14,6$ & $18 / 17,1$ & $>0,05$ \\
\hline \multicolumn{4}{|l|}{ Серцева недостатність (CH): } \\
\hline - І ФК за NYHA & $72 / 50,0$ & $57 / 54,3$ & $>0,05$ \\
\hline - 2a ФК за NYHA & $24 / 16,7$ & $14 / 13,3$ & $>0,05$ \\
\hline - $2 б$ ФК за NYHA & $3 / 2,1$ & $4 / 3,8$ & $>0,05$ \\
\hline Порушення ритму серця & $85 / 59,0$ & $66 / 62,9$ & $>0,05$ \\
\hline \multirow[t]{2}{*}{ Блокади ніжок пучка Гіса, в тому числі повні } & $35 / 24,3$ & $23 / 21,9$ & $>0,05$ \\
\hline & $13 / 9,0$ & $6 / 5,7$ & $>0,05$ \\
\hline рні блокади & $15 / 10,4$ & $14 / 13,3$ & $>0,05$ \\
\hline Супутній ЦД & $33 / 22,9$ & $25 / 23,8$ & $>0,05$ \\
\hline Гостре порушення мозкового кровообігу & $10 / 6,9$ & $3 / 2,9$ & $>0,05$ \\
\hline
\end{tabular}


а також особливостей функціонального стану ССС від поглиненої дози опромінення.

Виконано ретроспективний аналіз за період 1986-2012рр., який полягав в оцінці клінічного перебігу найпоширеніших СС3 з історій хвороб для порівняння їх із власними даними, отриманими у 2012-2016 рр. (поточний аналіз). Весь період спостереження умовно розподілено на три десятирічних етапи: $1986-$ 1996, 1996-2006 та 2006-2016 рр. Кожний УЛНА хоча б один раз проходив дослідження у клініці Державної установи «Національний науковий центр радіаційної медицини НАМН України» на кожному з етапів. При ретроспективному та поточному аналізі діагноз СС3 встановлювали/верифікували згідно з рекомендаціями Асоціації кардіологів України 2016 р., Європейського товариства кардіологів (European Society of Cardiology - ESC) 2013 р. та Американської асоціації серця (American Heart Association - AHA) 2012 p. (Fihn S.D. et al., 2012; Montalescot G. et al., 2013; Коваленко В.М. та співавт., 2016).

Клінічне обстеження включало загальний огляд, збір радіаційного анамнезу, фізичне обстеження, електрокардіографію, добовий моніторинг ЕКГ, стрес-тест із ЕКГ, ехокардіографію, лабораторні дослідження.

Статистичну обробку результатів проводили за допомогою комп'ютерної програми «SPSS 22», використовуючи алгоритм розрахунків згідно з А. Бююль, П. Цефель (2005). Використовували метод описової статистики, порівняння середніх (t-тест для незалежних вибірок та однофакторний дисперсійний аналіз - One-way ANOVA), аналіз таблиць спряженості, кореляційний та регресійний аналіз. Зі складніших статистичних методів застосовували дискримінантний аналіз, аналіз виживаності за Капланом - Мейєром та аналіз пропорційних ризиків.

\section{Результати та їх обговорення}

Аналізуючи дані щодо ССЗ серед УЛНА, виявили, що в перші 10 років після опромінення на ГХ захворіла найбільша кількість осіб, що достовірно перевищувало захворюваність на ГХ у КГ (99 та 17 осіб відповідно) (рис. 1).

ГХ у перші 10 років спостереження розвивалася переважно у людей віком 18-44 роки: серед УЛНА - у $66(66,7 \%)$ пацієнтів із 99, в КГ - у 10 (55,6\%) із 18 осіб. Середній вік осіб, які захворі-

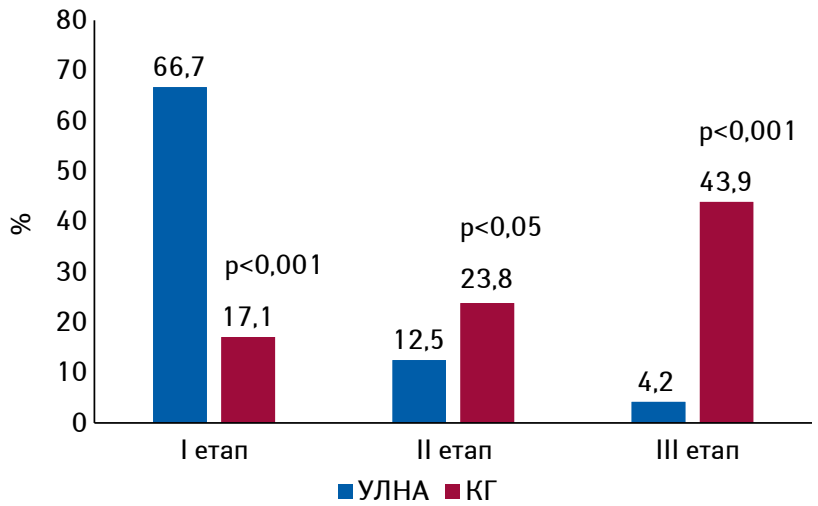

Рис. 1. Динаміка розвитку ГХ на етапах спостереження в УЛНА та осіб КГ

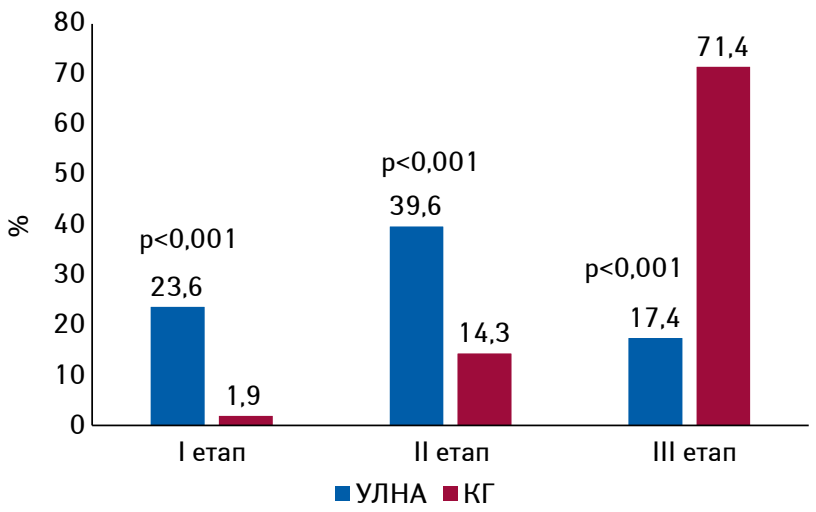

Рис. 3. Динаміка розвитку IXC на етапах спостереження в УЛНА та осіб КГ ли на ГХ на І етапі спостереження в УЛНА, становив $41,2 \pm 10,1$ року, незначно відрізняючись від аналогічного показника КГ $43,2 \pm 9,2$ року $(p=0,425)$. В наступні два десятиріччя після аварії кількість нових випадків ГХ серед УЛНА поступово зменшувалася (18 та 6 осіб). Динаміка розвитку ГХ серед осіб КГ була прямо протилежною: у перші 10 років на ГХ захворіло в 4 рази менше пацієнтів, ніж у групі УЛНА. У наступні роки їх кількість зросла, і за останне десятиріччя частка осіб, які захворіли в КГ, була в 10 разів більшою. Через 30 років після аварії ГX I стадії діагностовано у 14 УЛНА та 3 осіб КГ, ІІ стадії - 91 та 72 особи і III стадії18 та 13 осіб відповідно (рис. 2). При однаковій частці пацієнтів із ГX III стадії серед УЛНА і КГ в останній була більша відносна кількість осіб із ГХ ІІ стадії і вірогідно менша - із ГХ І стадії.

Серед УЛНА у перші 10 років на IXC захворіло вірогідно більше пацієнтів, ніж серед КГ (34 і 2 відповідно) (рис. 3). На II етапі зберігалася та сама закономірність, але кількість осіб, які захворіли на IXC, серед УЛНА була ще більшою (57 та 15 відповідно). Вік УЛНА, які захворіли на IXC за перші 20 років, був вірогідно молодший, ніж у КГ $-50,4 \pm 9,0$ та 58,2 $\pm 10,6$ року відповідно; $p=0,002$. На III етапі на IXC захворіли 25 УЛНА та 75 осіб КГ, що серед останніх було в 4,4 раза більше, ніж у попередні роки.

Таким чином, простежується загальна закономірність для УЛНА: переважна більшість нових випадків IXC та ГХ діагностовано в перші 20 років після аварії. Більшість осіб КГ захворіли на ГХ та IXC через 20-30 років після аварії.

Усіх пацієнтів, які перенесли IM, включали в програму обстеження не раніше ніж через 1 рік після гострого IM. На І етапі IM перенесли 6 УЛНА, на II - 12 УЛНА та 2 учасники КГ, на III - 3 УлНА та 16 осіб КГ (рис. 4). Серед УЛНА 6 осіб перенесли повторний IM, чого не відзначено серед пацієнтів КГ. Це свідчить про більш раннє прогресування IXC з розвитком тяжких кардіоваскулярних подій серед УЛНА

Для вивчення динаміки розвитку ССЗ використовували аналіз таблиць виживаності за методом Каплана - Мейєра, як це описано А. Бююль, П. Цефель (2005). Результати аналізу свідчать, що сумарна частка пацієнтів, які захворіли на ГХ та IXC у процесі старіння, швидше збільшувалася в УЛНА порівняно з КГ (рис. 5), тобто УЛНА занедужували на ГХ та IXC у вірогідно молодшому віці, ніж особи КГ — лог-ранговий тест: $\chi^{2}=30,404$

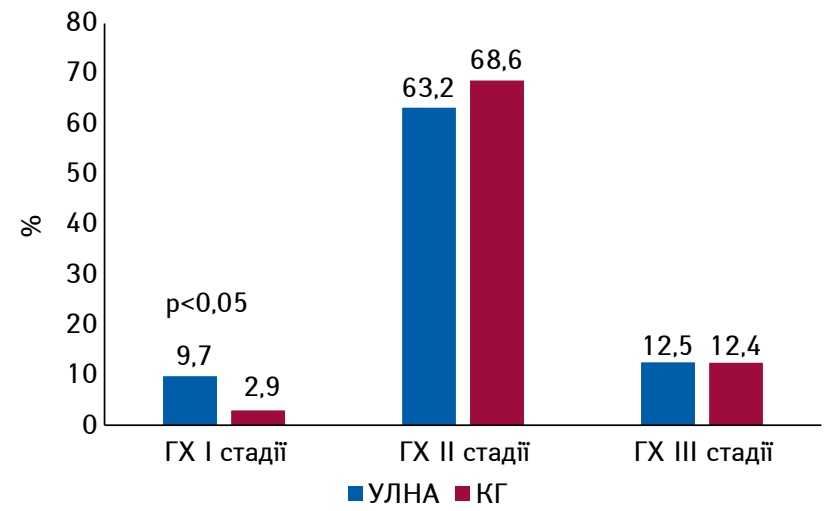

Рис. 2. Розподіл УЛНА та осіб КГ через 30 років після аварії залежно від стадії ГХ

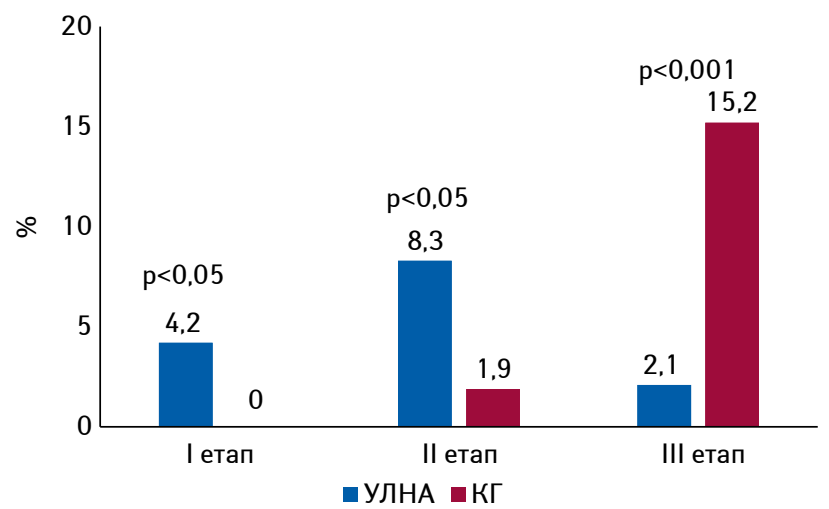

Рис. 4. Динаміка розвитку IM на етапах спостереження в УЛНА та осіб КГ 
$(p=0,000)$ для ГX та $X^{2}=45,849(p=0,000)$ для IXC. Ця різниця становила 12,1 та 9,8 року за показниками середньої та 11,7 та 10,5 року - за медіаною виживаності для ГX та IXC відповідно (табл. 2). Дані медіани виживаності висвітлюють те, що по досягненню всіма УЛНА віку 45 років накопичена захворюваність на ГХ становила $50 \%$, тоді як у КГ цей вік становив 56,7 року. До досягнення пацієнтами 50-річного віку серед УЛНА частка хворих на ГХ становила $64,1 \%$, IXC - 38,2\%, в КГ - 28,6 і 8,6\% відповідно, по досягненню 60 років - 83,9 і 81,9\% та 55,9 і 34,4\% відповідно. Для вивчення феномену, наскільки швидко після опромінення УЛНА захворювали на IXC та ГX, використано той самий метод аналізу таблиць виживаності, але замість віку пацієнта за часову шкалу прийнято показник часу, що минув після аварії.

Порівняно з КГ УЛНА можна очікувати іншу динаміку накопиченої частоти ГХ та IXC, що спричинено впливом радіаційного фактора. Дійсно, кількість пацієнтів із ГХ та IXC в УЛНА збільшувалася стрімкішими темпами, ніж у КГ (рис. 6, табл. 3). В УЛНА середня величина функції виживаності для ГХ була на 10,5 року, для IXC - на 8,4 року меншою, ніж у КГ. Медіана функції виживаності показала, що накопичена захворюваність на ГХ рівнем $50 \%$ припадає на 16 , на IXC - на 10 років раніше, ніж в осіб КГ - лог-ранговий тест: $\chi^{2}=34,399(p=0,000)$ для ГХ та $\chi^{2}=45,835(p=0,000)$ для IXC. Через 10 років після опромінення в УЛНА ГХ розвинулась у $68,7 \%$, в КГ - лише у $17,1 \%$ пацієнтів. Ще через 10 років ГХ виявлено вже у $81,8 \%$ УлНА та у $41,9 \%$ осіб КГ. За період $20-30$ років після аварії накопичена частота ГХ в УЛНА становила 87,5\%, в КГ - 57,1\%, IXC 96,6 та $100 \%$ відповідно.

Аналіз графіків виживаності після перенесеного IM (рис. 7) показав наявність візуальних відмінностей між кривими, побудованими для УЛНА та осіб КГ, незалежно від того, чи взятий для часової шкали вік пацієнта або роки, що минули після аварії. Однак лог-ранговий тест показав, що три роки різниці значення показника середньої функції виживаності для віку на момент розвитку IM та 0,9 року для часу, що минув після аварії, не є достовірними величинами (табл. 4).

До аварії всі особи, які брали участь в аварійних роботах, не мали ознак ендокринної патології; те саме стосувалося і пацієнтів КГ. У післяаварійні роки ЦД 2-го типу розвинувся у 33 УЛНА і 25 осіб КГ, причому у $2(6,1 \%)$ УЛНА і $2(8,0 \%)$ осіб КГ ЦД діагностували раніше, ніж ГХ. У 11 (33,3\%) УЛНА і 6 (24,0\%) осіб КГ ЦД випереджав розвиток IXC. В інших обстежених ЦД розвинувся на фоні вже наявних ГX та IXC.

Аналіз таблиць виживаності за Капланом - Мейєром і графіків динаміки кумулятивної захворюваності показав, що середУЛНА ЦД2-го типу розвивався в молодшому віці порівняно з КГ (рис. 8а, табл. 5). Так, у віковому діапазоні 40-80 років при однаковому віці обстежених осіб відносне число хворих було більшим у групі УлНА. Лог-ранговий тест не показав вірогідність відмінностей графіків $\left(\chi^{2}=2,789 ; p=0,095\right)$, проте два інші критерії, Бреслоу і Терона Уера, підтвердили вірогідність відмінностей динаміки кривих ку-
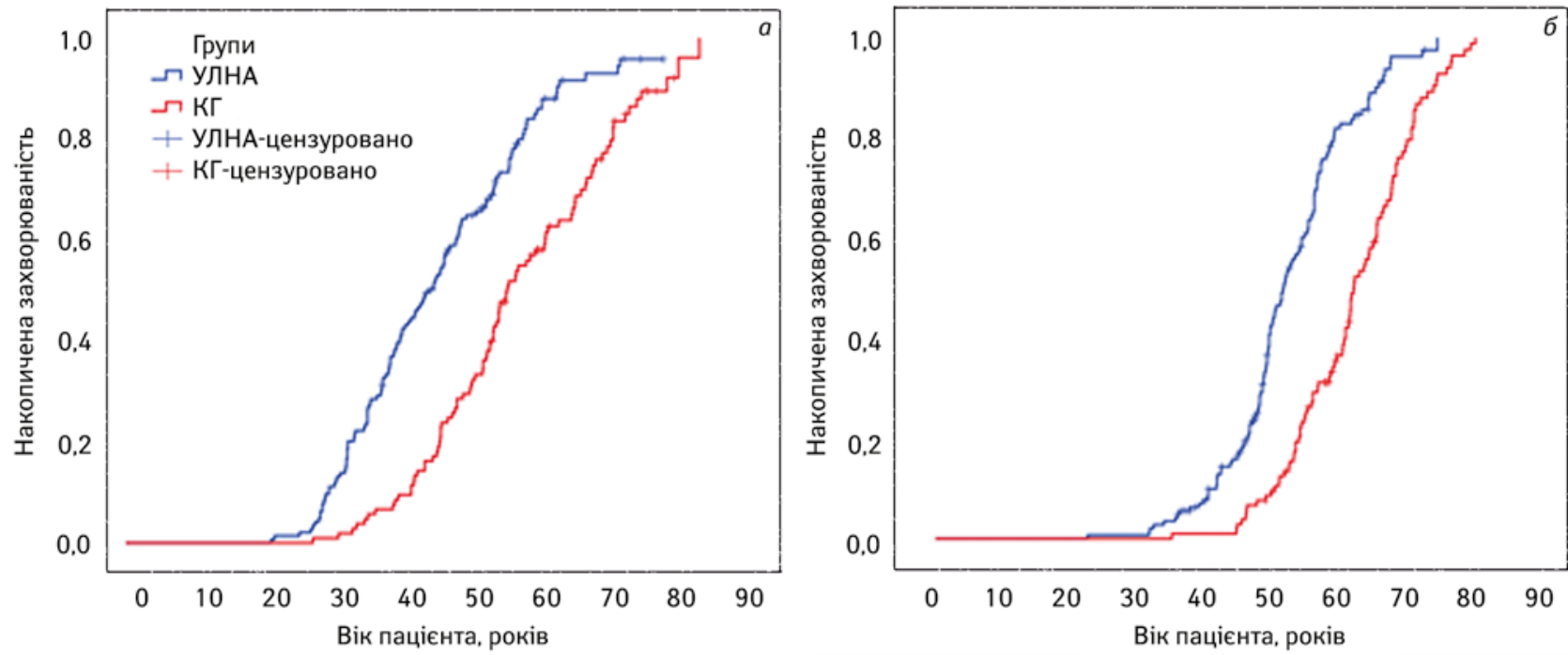

Рис. 5. Динаміка накопиченої частки УЛНА та осіб КГ, які захворіли на ГХ (а) та ІХC (б), у процесі старіння
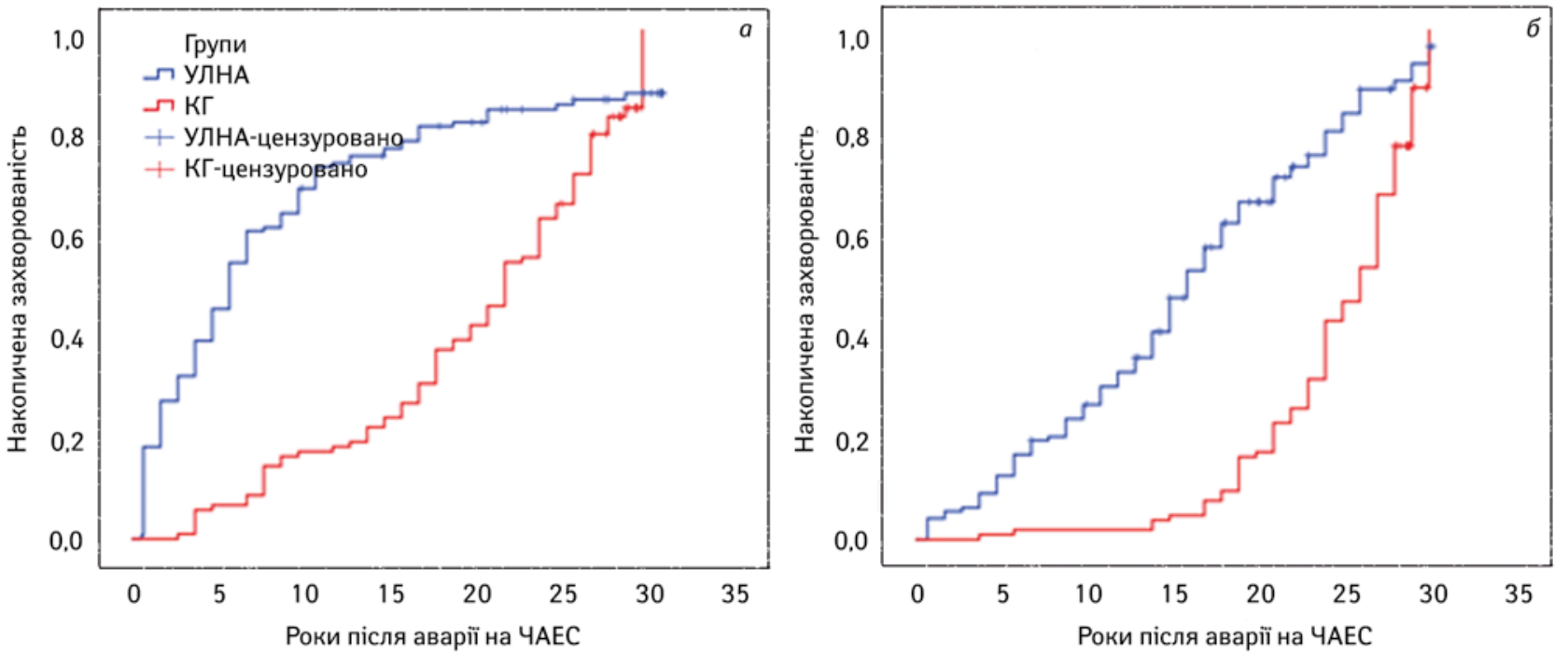

Рис. 6. Динаміка накопиченої частки УЛНА та осіб КГ, які захворіли на ГХ (а) та IXC (б), залежно від терміну після аварії 

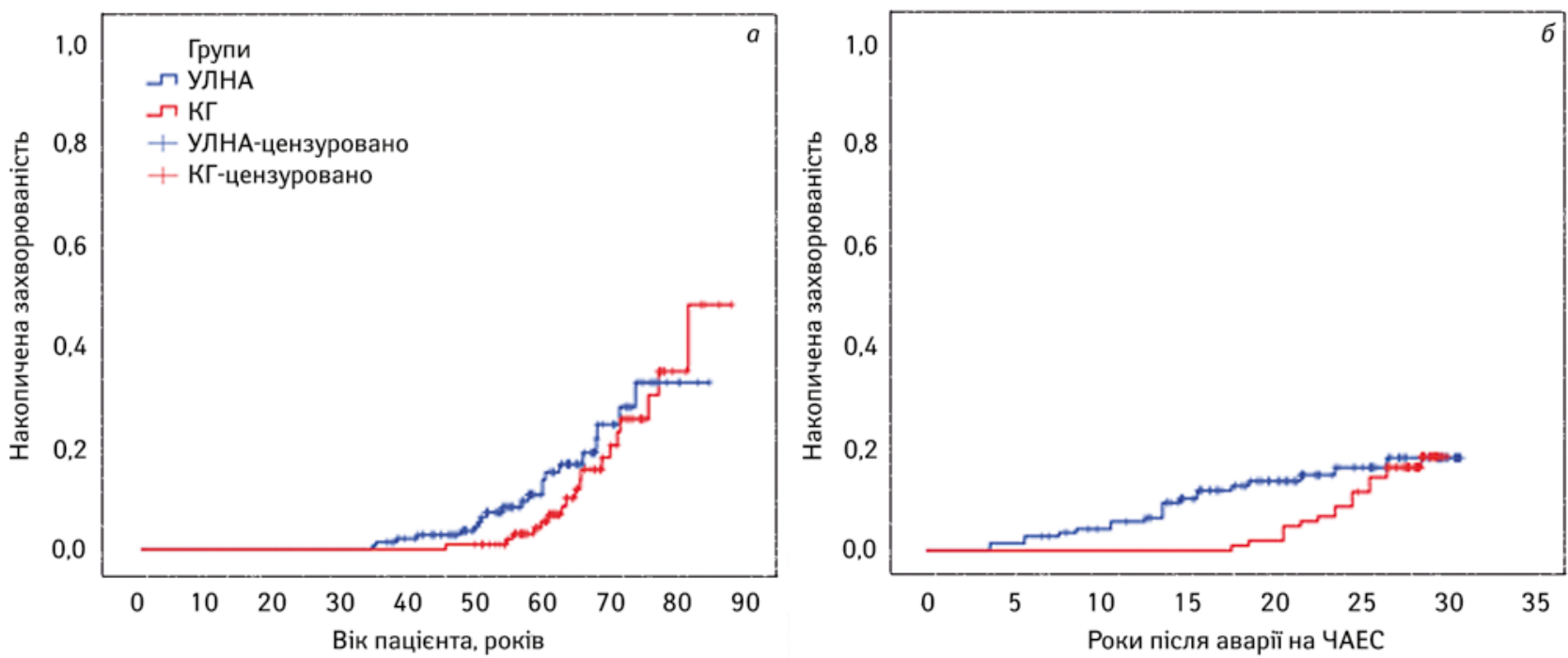

Рис. 7. Динаміка накопиченої частки УЛНА та особи КГ, які перенесли IM, у процесі старіння (а) та залежно від періоду після аварії (б)
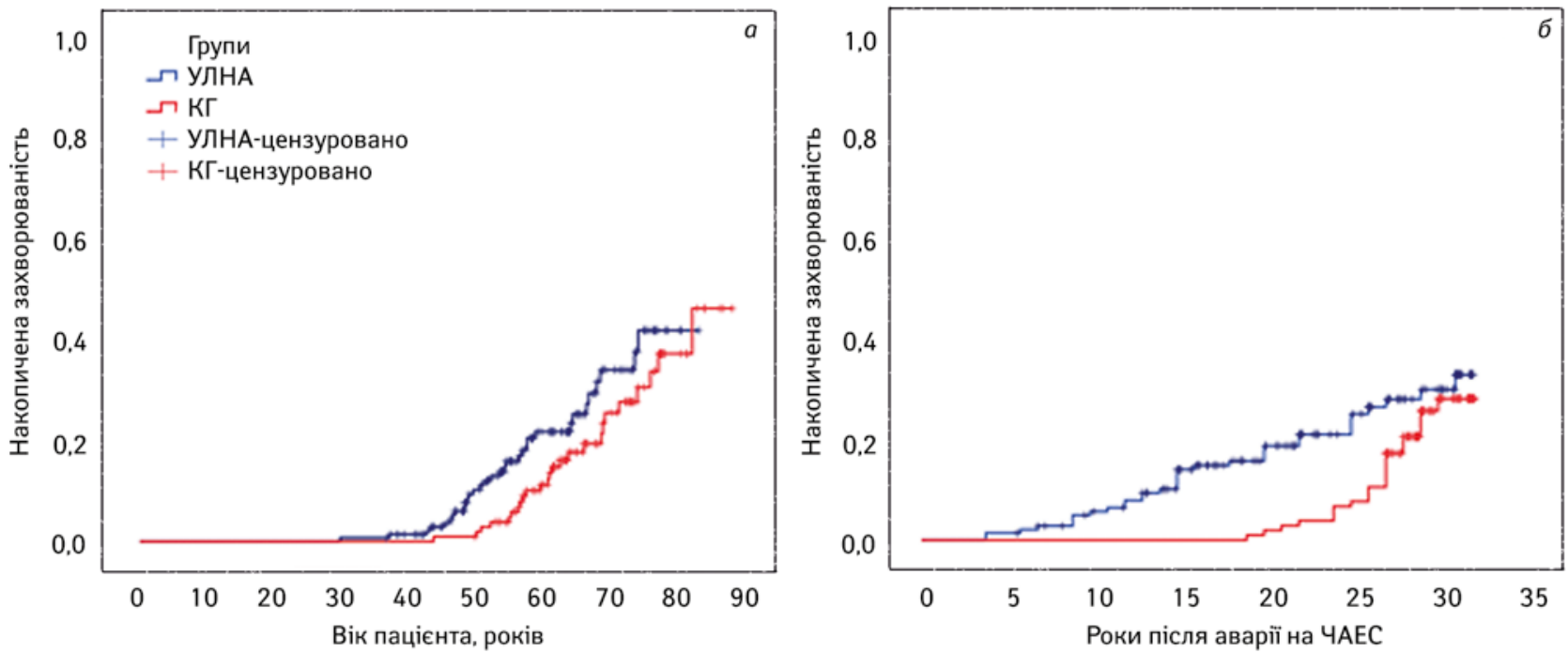

Рис. 8. Динаміка накопиченої частки УЛНА та осіб КГ, які захворіли на ЦД 2-го типу, залежно від віку (а) і терміну після аварії (б)

мулятивної захворюваності: $\chi^{2}=5,018(p=0,025)$ і $\chi^{2}=4,102$ $(\mathrm{p}=0,043)$.

Вивчення захворюваності на ЦД у післяаварійний період показало, що частка захворілих на будь-якому часовому відрізку була більшою серед УЛНА порівняно з КГ, про що свідчили візуальні відмінності кривих (рис. 8б) і значення середніх часу виживаності. Достовірність відмінностей динаміки кривих кумулятивної

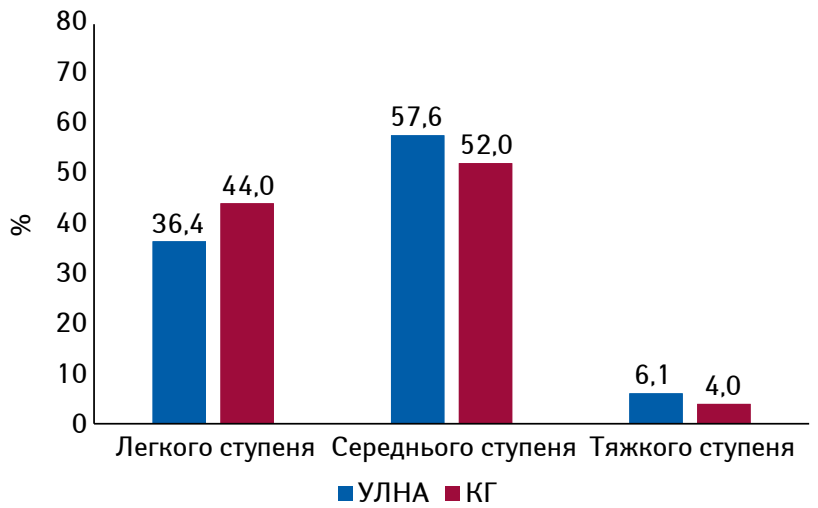

Рис. 9. Відносна кількість УЛНА та осіб КГ із ЦД 2-го типу залежно від тяжкості його перебігу через 30 років після аварії захворюваності підтвердили критерії Бреслоу $\left(\chi^{2}=8,239 ; p=0,004\right)$ і Терона - Уера $\left(\chi^{2}=5,930 ; p=0,015\right)$, але спростовував логранговий тест $\left(\chi^{2}=3,628 ; p=0,057\right)$. Перші випадки захворювання на ЦД 2-го типу виявлені вже через 5 років після опромінення.

Як серед УЛНА, так і серед осіб КГ ГХ і ІХC розвивалися у молодшому віці і в більш ранні періоди після аварії порівняно з Цд. Різниця середнього віку УлНА, у яких вперше діагностували ГХ

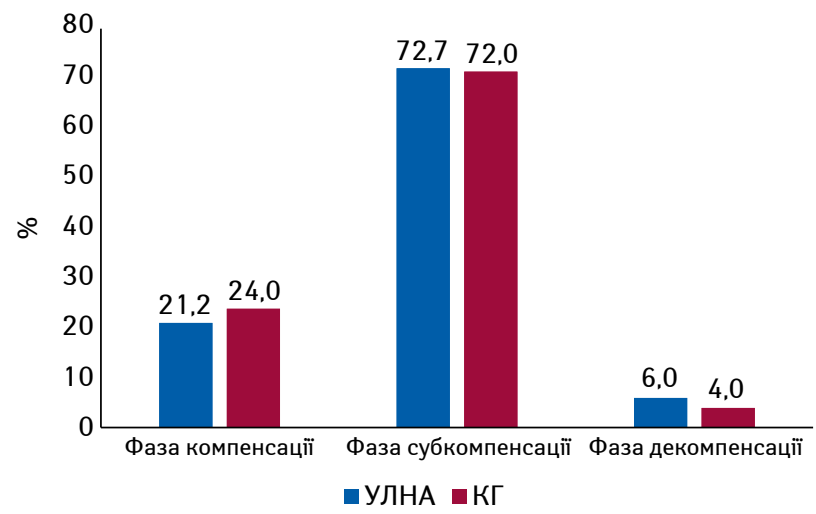

Рис. 10. Відносна кількість УЛНА та осіб КГ залежно від ступеня компенсації ЦД 2-го типу через 30 років після аварії 
Таблиця 2. Середня та медіана (показник \pm стандартна похибка) часу виживаності (вік пацієнта, років) при розвитку ГХ та IXС в УЛНА та КГ

\begin{tabular}{lccccc}
\hline Захворювання & Група & Середня & 95\% ДІ & Медіана & 95\% ДІ \\
\hline ГХ & УЛНА & $46,8 \pm 1,2$ & $44,5-49,1$ & $45,0 \pm 1,9$ & $41,3-48,7$ \\
& КГ & $58,9 \pm 1,4$ & $56,2-61,6$ & $56,7 \pm 1,8$ & $53,2-60,2$ \\
ІХС & УЛНА & $53,1 \pm 0,8$ & $51,5-54,8$ & $52,3 \pm 1,1$ & $50,1-54,5$ \\
& КГ & $62,9 \pm 0,9$ & $61,1-64,7$ & $62,8 \pm 1,1$ & $60,7-64,9$ \\
\hline
\end{tabular}

Таблиця 3. Середня та медіана (показник \pm стандартна помилка) часу виживаності (роки після аварії) при розвитку ГX та IXC в УЛНА та осіб КГ

\begin{tabular}{lccccc}
\hline Захворювання & Група & Середня & $\mathbf{9 5 \%}$ ДІ & Медіана & $\mathbf{9 5 \%}$ ДІ \\
\hline ГХ & УЛНА & $9,7 \pm 0,8$ & $8,1-11,4$ & $5,7 \pm 0,6$ & $4,6-6,8$ \\
& КГ & $20,2 \pm 0,8$ & $18,6-21,7$ & $21,7 \pm 1,1$ & $19,6-23,8$ \\
ІХС & УЛНА & $15,9 \pm 0,7$ & $14,5-17,3$ & $15,7 \pm 0,8$ & $14,2-17,2$ \\
& КГ & $24,3 \pm 0,5$ & $23,4-25,3$ & $25,7 \pm 0,6$ & $24,5-26,9$ \\
\hline
\end{tabular}

Таблиця 4. Середня (показник \pm стандартна помилка) часу виживаності (вік пацієнта та роки після аварії) при розвитку ІМ в УЛНА та осіб КГ

\begin{tabular}{lcccc}
\hline \multicolumn{1}{c}{ Шкала часу } & Група & Середня & 95\% ДІ & $\begin{array}{c}\text { Лог-ранговий } \\
\text { тест, p }\end{array}$ \\
\hline Вік пацієнтів & УЛНА & $76,6 \pm 1,5$ & $73,8-79,5$ & 0,333 \\
Термін після аварії & КГ & $79,6 \pm 1,6$ & $76,6-82,7$ & \\
& УЛНА & $29,0 \pm 0,3$ & $28,5-29,6$ & 0,340 \\
\hline
\end{tabular}

Таблиця 5. Середня (показник \pm стандартна помилка) часу виживаності (вік пацієнта та роки після аварії) при розвитку ЦД 2-го типу в УЛНА та осіб КГ

\begin{tabular}{lccc}
\hline \multicolumn{1}{c}{ Шкала часу } & Група & Середня & 95\% ДІ \\
\hline Вік пацієнтів & УЛНА & $72,5 \pm 1,4$ & $69,7-75,3$ \\
& КГ & $78,4 \pm 1,5$ & $75,5-81,4$ \\
Період після аварії & УЛНА & $27,4 \pm 0,7$ & $26,1-28,7$ \\
& КГ & $30,2 \pm 0,3$ & $29,6-30,8$ \\
\hline
\end{tabular}

і ЦД, становила 25,7 року (лог-ранговий тест: $\left.\chi^{2}=134,3 ; p=0,000\right)$, а серед осіб КГ - 19,5 року (лог-ранговий тест: $\chi^{2}=70,7 ; p=0,000$ ). IXC в УЛНА діагностували в середньому на 19,4 року раніше за ЦД (лог-ранговий тест: $\left.\chi^{2}=106,2 ; p=0,000\right)$, в КГ - на 15,5 року (логранговий тест: $\left.\chi^{2}=68,7 ; p=0,000\right)$.

До кінця 3-го десятиліття після аварії як серед УлНА, так і в КГ найчастіше відзначали ЦД 2-го типу середнього ступеня тяжкості (19 і 13 пацієнтів відповідно), рідше - цд легкого (12 та 11 пацієнтів) і зовсім рідко - ЦД тяжкого перебігу (2 УЛНА та 1 хворий КГ) (рис. 9). Між УЛНА і КГ не виявлено достовірних статистичних відмінностей за частотою тяжкості перебігу ЦД. Менше ніж у чверті УЛНА (n=7) і осіб КГ (n=6) була стадія компенсації ЦД на тлі дієти і медикаментозного лікування без інсулінотерапії (рис. 10). Стадія субкомпенсації ЦД виявлена у більшості УЛНА (n=24) і осіб КГ (n=18). У двох УЛНА і одного хворого КГ відзначали декомпенсацію ЦД, яку вдалося перевести у фазу субкомпенсації підвищенням дози антигіперглікемічних препаратів для двох пацієнтів і переведенням одного з УлНА на інсулінотерапію.

Через 30 років після аварії ЏД розвинувся у 32 (97,0\%) УлНА і 24 (96,0\%) осіб КГ, у яких діагностовано ГХ (рис. 11). Середцих осіб у $29(87,9 \%)$ УЛНА і $21(84,0 \%)$ пацієнта КГ џД був без ознак IXC. По одній особі з групи УЛНА кожної групи ЦД не поєднувався з IXC. Достовірних відмінностей між УЛНА і пацієнтами КГ щодо частоти поєднання ЦД із ГX і IXC не виявлено. Результати аналізу таблиць спряженості свідчать, що серед УЛНАіпацієнтів КГ розвитокЦДбув вірогідно пов'язаний із ГХ ( $\chi^{2}$ Пірсона=8, 159; $p=0,003)$. Наявність ГХ підвищувала ризик розвитку џД у 6,503 раза (95\% довірчий інтервал (ДІ) 1,516-27,899). ІХC, яка виникала раніше ЦД, достовірно не впливала на розвиток останнього ані серед УЛНА, ані серед КГ: $\chi^{2}$ Пірсона=0,510 ( $\left.p=0,552\right)$.

Для осіб із ЦД 2-го типу, як УЛНА, так і КГ, був характерний тяжчий перебіг ГХ, який полягав у наявності більшої частки пацієнтів із ГX II і III стадії (рис. 12). Серед осіб без ЦД була більшою частка пацієнтів без ГX ( $p<0,001$ для УЛНА і $p<0,01$ для КГ) і з ГХ І стадії ( $p<0,05$ для УЛНА і $p>0,05$ для КГ). Серед УЛНА із ЦД була більшою відносна кількість пацієнтів із ГХ ІІІ стадії ( $n=9)$ порівняно з КГ (n=5), а в останніх, навпаки, більше пацієнтів із ГX II стадії (19 та 22 особи відповідно), однак розбіжності були недостовірними. Таким чином, можна припустити, що ЦД, розвиваючись пізніше ГХ, модифікував перебіг останньої, обтяжуючи його.

Явища СН виявлені у 29 УЛНА із ЦД і $69-$ без ЦД, а також у 20 осіб КГ із ЦД і 56 - без ЦД. СН І стадії виявлена у більшості пацієнтів обох груп, як з діагнозом ЦД, так і без нього (рис. 13). Серед УЛНА із ЦД виявлено найбільше пацієнтів із $\mathrm{CH}$ Ila і CH ІІб стадії, що свідчить про більш несприятливий перебіг ІХС. Не виявлено достовірних відмінностей частоти $\mathrm{CH}$ різних стадій між основною та КГ, незалежно від наявності ЦД, але відзначено, що серед УЛНА без ЦД взагалі не було пацієнтів із СН ІІб стадії, а в КГ без Цд іх було 2.

До аварії частка осіб з нормальною масою тіла (НMT) (індекс маси тіла (IMT) 18,5-24,99 кг/м²) була більшою серед осіб КГ порівняно з УЛНА (рис. 14). УКГ також було більше осіб з ожирінням (IMT $\geqslant 30$ кг $\left./ \mathrm{M}^{2}\right)$, але відмінності були недостовірними. Серед УЛНА відзначено статистично достовірне переважання пацієнтів із надмірною масою тіла (НдМТ) (IMT 25-29,99 кг/м²). В УЛНА ожиріння І ступеня (IMT 30-34,99 кг/М²) відзначено у 6 (4,2\%), ІІ ступеня (IMT $\left.35-39,99 \mathrm{kr} / \mathrm{M}^{2}\right)$ - у $2(1,4 \%)$ осіб, III ступеня (IMT $\left.\geqslant 40 \mathrm{kг} / \mathrm{M}^{2}\right)-$ не спостерігали, оскільки осіб з цим ступенем ожиріння не залучали до участі у дослідженні. Ожиріння I ступеня виявлено у $6(5,7 \%)$, II ступеня - у $5(4,8 \%)$, III ступеня - у $1(1,0 \%)$ пацієнтів КГ.

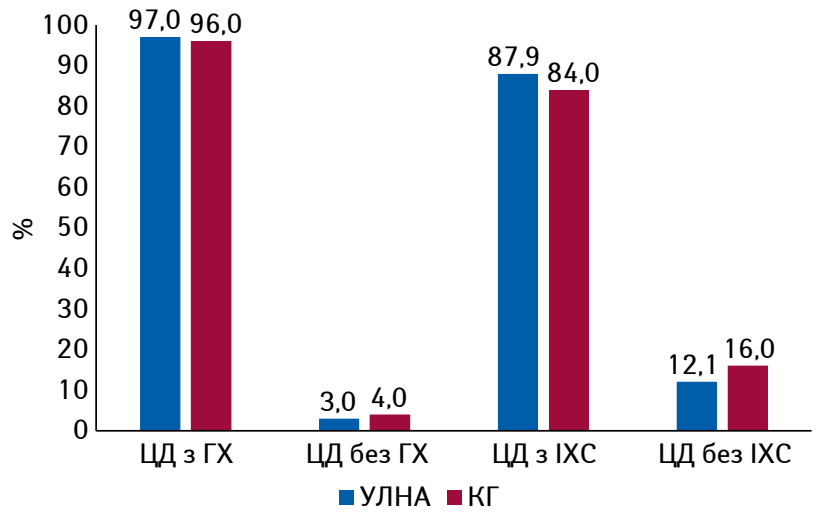

Рис. 11. Відносна кількість УЛНА та осіб КГ із ЦД 2-го типу в поєднанні з ГХ та IXC через 30 років після аварії

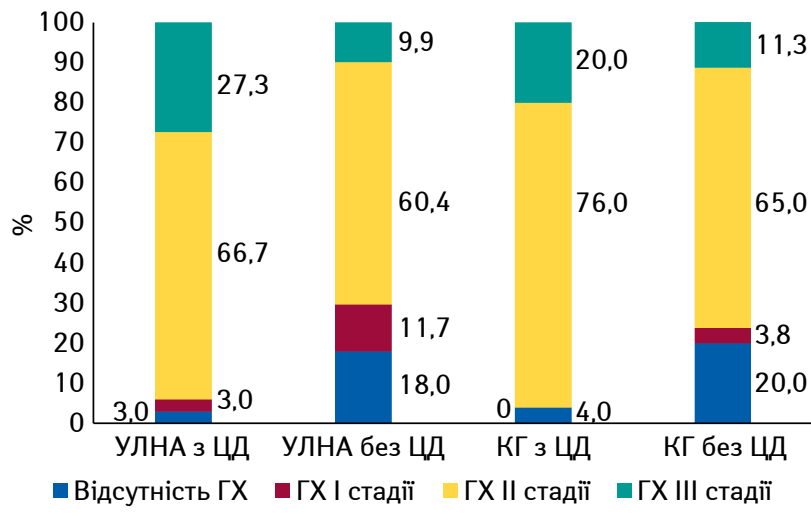

Рис. 12. Відносна кількість УЛНА та осіб КГ із ГХ різних стадій з/без ЦД 2-го типу через 30 років після аварії

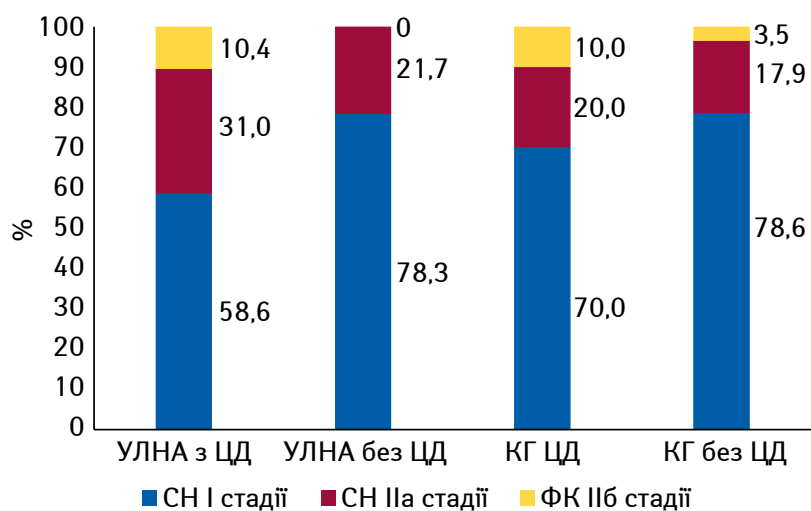

Рис. 13. Відносна кількість УЛНА та осіб КГ із СН різної стадії з/без цД 2-го типу через 30 років після аварії 


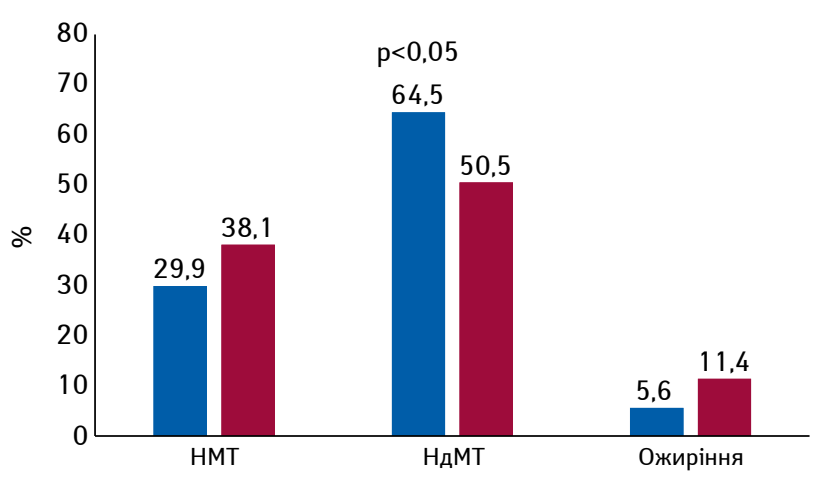

$\square$ УЛНА

Рис. 14. Відносна кількість УЛНА та осіб КГ з НМТ та НдМТ до аварії

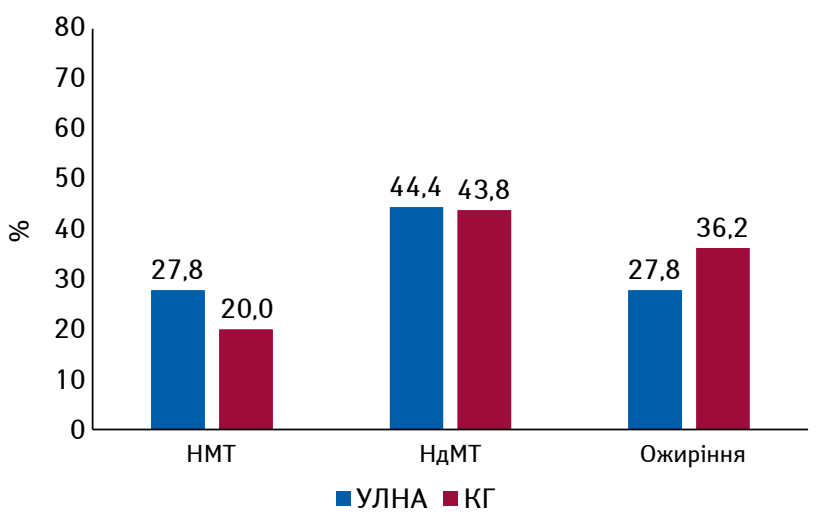

Рис. 15. Відносна кількість УЛНА та осіб КГ з НМТ та НдМТ через 30 років після аварії

Аналіз динаміки розвитку ожиріння серед осіб з НМТ і НдМТ за методом Каплана - Мейєра показав, що графіки накопичення нових випадків ожиріння в УЛНА і КГ мали достовірні відмінності відповідно до критеріїв Бреслоу $\left(x^{2}=6,581 ; p=0,010\right)$ і Терона - Уера $\left(x^{2}=4,549 ; p=0,033\right)$. У віковому діапазоні $30-75$ років показник накопиченої захворюваності був вищий в УЛНА порівняно з особами КГ. Показник середньої виживаності в УлНА, де за шкалу

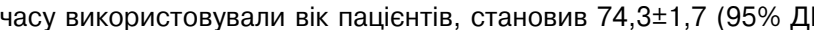
70,9-77,7), в КГ - 78,4 1,5 (95\% ДІ 75,4-81,4) року. Середній вік УЛНА і осіб КГ, при якому розвивалося ожиріння, був достовірно вищим, ніж показники середнього віку для ГX та IXC. Ожиріння передувало розвитку ГХ у 9 (6,3\%) УЛНА і 10 (9,5\%) осіб КГ, ІХC $20(13,9 \%)$ і 9 (8,6\%) відповідно. Таким чином, у 112 (77,8\%) УлНА і 78 (74,3\%) осіб КГ ГХ розвинулася раніше, ніж ІМТ у пацієнтів став перевищувати $30 \mathrm{kг} / \mathrm{M}^{2}$. IXC діагностовано раніше, ніж ожиріння, у $96(66,7 \%)$ улНА і $82(78,1 \%)$ осіб КГ. У $71(49,3 \%)$ УЛНА і $59(56,2 \%)$ осіб КГ вже була НдМТ, включаючи ожиріння, коли в них вперше діагностували ГХ. Те саме стосувалося $72(50,0 \%)$ УЛНА і 60 (57,1\%) осіб КГ, коли в них виявили IXC.

Через 30 років кількість пацієнтів із НМТ зменшилася серед УЛНА на 3 особи, в КГ - вдвічі. Частка пацієнтів із ожирінням зросла у групі УЛНА у 5, в КГ - у 3 рази. Частка осіб з ожирінням серед УЛНА зростала переважно за рахунок пацієнтів, в яких була НдМТ (рис. 15). В КГ кількість осіб з ожирінням також збільшувалася за рахунок зростання IMT $>30 \mathrm{kr} / \mathrm{M}^{2}$ у пацієнтів з НдМТ, але при цьому 18 осіб з НМТ перейшли в категорію «НдМТ».

Для вивчення динаміки ССЗ застосований метод аналізу таблиць виживаності Каплана - Мейєра, який дозволяв уникнути втрат даних про пацієнта, якщо він вибував з-під спостереження на останньому етапі. Крім того, він давав візуальне уявлення про розвиток патології (у нашому випадку - ГX та IXC) за певний період (у нашому випадку - вік пацієнта та час після аварії). Якщо простий аналіз появи нових випадків ССЗ на кожному з трьох 10-річних періодів, що минули після аварії, показав, що в перші 10-20 років в УЛНА зареєстровано $81,3 \%$ випадків ГХ і 63,2\% IXC, то метод Каплана - Мейєра показував розгорнуту динаміку за всі роки. Починаючи з 35-літнього віку і до 75-80 років відносна кількість захворілих на ГХ та IXC серед УЛНА було вірогідно більшою, ніж у КГ, що показав лог-ранговий тест. Іншими словами, яку би вікову групу не аналізували, частота розвитку ССЗ в УЛНА була вищою.

Якщо прийняти за шкалу часу роки, що минули після аварії, то за перші 11 років в УЛНА розвинулися $73 \%$ усіх випадків ГХ; така сама кількість осіб КГ захворіли лише через 26 років. Кількість УлНА, які захворіли на IXC, рівномірно зростала протягом усіх років після аварії, а в КГ 68,6\% пацієнтів захворіли за останні 6 років, тобто КГ «наздоганяла» УЛНА за частотою ГХ та IXC лише через 30 років після аварії.

Існують повідомлення про більш ранній розвиток ССЗ в УЛНА. Обстеживши за період 2006-2011 рр. 691 УлНА та 129 осіб КГ, отримано достатньо високі показники поширеності ССЗ в УЛНА (758,3 на 1000 осіб) і КГ (596,9 на 1000 осіб), але при цьому поширеність АГ в УЛНА 1986 р. була 18,3\%, 1987 р. - 19,9\%. Для IXC ці показники становили 15,9 і 13,3\% відповідно. Застосовуючи непараметричні тести (Манна - Уїтні та Колмогорова - Смирнова), також виявлено, що в УЛНА ССЗ розвиваються раніше, ніж в КГ (Мешков Н.А., 2016). Про ранній розвиток ІХС в УЛНА повідомляли й інші автори (Телкова И.Л., 2010), але не проводили зіставлення з КГ.

У дослідженнях інших авторів (Каташкова Г.Д. и соавт., 2002; Поровский Я.В., 2015) показано, що для УЛНА характерна поліорганність патології. Вже через 10-14 років після участі у відновних роботах на одного УЛНА доводилося 5-13 захворювань (в середньому $-8,2$ ), причому патологія ССС поєднувалася із хворобами шлунково-кишкового тракту, дихальної та кістковом'язової системи. Однак не повідомляли, чи сформувалася ця патологія до чи після аварії.

У більшості робіт, присвячених КЗ, повідомляли про одночасне зростання кількості АГ, IXC та ЦД 2-го типу серед населення розвинених країн в останні десятиліття. Поєднання цих захворювань характеризується взаємним потенціюванням клінічного перебігу: наприклад, випереджаючи ЦД в своєму розвитку, ССЗ підвищують ризик його виникнення та $є$ основною причиною смерті при ЦД, а ЦД, з'явившись першим, призводить до швидкого розвитку IXC (Обрезан А.Г., 2008; Лупанов В.П., 2013).

У проведеному нами дослідженні виявлена така характерна особливість прояву КЗ: спочатку як серед УЛНА, так і серед осіб КГ, розвивалася ГХ, потім до неї приєднувалась IXC, а потім - ЦД 2-го типу, конкуруючи за термінами появи з IXC. Так, якщо лише у двох хворих основної та КГ ЦД випереджав розвиток ГХ, то у $1 / 3$ УЛНА і $1 / 4$ осіб КГ ЦД діагностували раніше за IXC.

Узагальнюючи дані декількох досліджень, А.Г. Обрезан (2008) показав, що атеросклероз при ЦД має низку таких особливостей: розвивається на 8-10 років раніше порівняно з особами без цд; розпізнається ще на стадії порушення толерантності до глюкози; значно швидше прогресує, його перебіг відбувається у тяжчій формі; атеросклеротичне ураження носить двобічний полісегментарний характер, частіше локалізується в судинах середнього діаметра. Патогенетична обґрунтованість цих тверджень не викликає сумнівів, але отримані нами результати лише частково відповідають їм. Так, періоди розвитку IXC у тих, хто вже захворів на ЦД, і тих, хто не захворів, достовірно не відрізнялися між собою. У пацієнтів із ЦД була більшою частка осіб зі стенокардією вищого ФК (II-III) і CН вищої стадії (Ila і IIб), а також ГX II і III стадії, однак ці відмінності не були достовірними. Припускаємо, що причина відсутності достовірності відмінностей полягає в занадто короткому періоді спостереження: 30 років виявилися достатніми для аналізу радіаційного фактора, а тривалості захворювання ЦД $(11,3 \pm 6,9$ року для УЛНА і 4,4 $\pm 3,4$ року - для КГ), імовірно, недостатньо для прояву всіх негативних механізмів його впливу, тим більше, що у переважної більшості пацієнтів із ЦД він перебував у фазі компенсації або субкомпенсації.

\section{Висновки}

Результати дослідження частоти виникнення нових випадків ГX та IXC на всіх етапах спостереження, а також накопиченої частоти цих нозологій залежно від віку та часу, що пройшов після аварії, свідчать, що після участі в аварійних роботах ГX, IXC, ЦД 2-го типу та ожиріння в УЛНА розвивались у більш ранній термін і в молодшому віці порівняно з особами КГ.

Переважна кількість УЛНА захворіли на ГХ в перші 10 років, осіб КГ - під час 2-го та 3-го десятиріччя після аварії. В усіх УЛНА 
ознаки IXC виявлені в перші 20 років після опромінення, в осіб КГ - в 3-му десятиріччі періоду спостереження.

У переважної більшості УЛНА та осіб КГ ЦД та ожиріння з'являлися на тлі раніше розвиненої кардіальної патології у вигляді ГХ та ІХС. У 93,9\% УЛНА розвиток ГХ достовірно випереджав клінічний дебют ЦД на 25,7 року, а у 66,7\% УЛНА розвиток IXC на 19,4 року. у $92,0 \%$ осіб КГ ця різниця становила 19,5 та у $76,0 \%-15,5$ року відповідно.

ГХ вірогідно підвищувала ризик розвитку ЦД 2-го типу як в УЛНА, так і у КГ, тоді як IXC не зумовлювала подібного впливу. У осіб із ГХ та IXC у поєднанні з ЦД частіше відзначено ГX II і III стадії, стенокардію ІІІ ФК і СН ІІб стадії. Більше половини УЛНА та осіб КГ мали НдМТ або ожиріння, коли в них розвинулися ГХ та IXC.

Участь у ліквідації наслідків аварії в поєднанні із впливом іонізуючого випромінювання можна вважати вірогідним фактором ризику ГX, IXC і ЦД 2-го типу.

\section{Список використаної літератури}

Аметов А.С., Лысенко М.А. (2011) Сахарный диабет 2-го типа и сердечно-сосудистые заболевания как столкновение двух глобальных неинфекционных эпидемий. Междунар. эндокринол. журн., 7: 56-59.

Бююль А., Цефель П. (2005) SPSS: искусство обработки информации Анализ статистических данных и восстановление скрытых закономерностей. «DiaSoft», Москва, Санкт-Петербург, Киев, 603 c.

Галяви Р.А., Михопарова О.Ю., Ощепкова О.Б., Фролова Э.Б. (2014) Артериальная гипертензия и сахарный диабет. Вест. совр. клин. мед., 7(1): 78-81.

Дементьев В.Е., Бицадзе Р.М., Обрезан А.Г., Крысюк О.Б. (2010) Актуальные вопросы кардиологической патологии у больных сахарным диабетом 2 типа. Вест. СПбГУ, 11(2): 44-50.

Древаль А.В. (2018) Менопауза (лекция). РМЖ, 1: 3-7.

Каташкова Г.Д., Бонитенко Ю.Ю., Никифоров А.М. и др. (2002) Соматическая патология у ликвидаторов последствий аварии на Чернобыльской АЭС. Заболевания сердечно-сосудистой системы. Патология отдаленного периода у ликвидаторов последствий аварии на Чернобыльской АЭС. Бином, Москва, 165-185.

Кваша Е.А. (2005) Распространенность избыточной массы тела и показатели смертности у мужчин в возрасте 40-59 лет, проживающих в г. Киеве (по данным проспективного исследования). Укр. кардіол. журн., 6: 109-111.

Коваленко В.М., Лутай М.І., Сіренко Ю.М., Сичов О.С. (2016) Серцево-судинні захворювання. Класифікація, стандарти діагностики та лікування. МОРІОН, Київ, 192 с.

Лупанов В.П. (2013) Ишемическая болезнь сердца и сахарный диабет: вопросы диагностики, медикаментозного и хирургического лечения, прогноз (обзор). Мед. совет, 3: 52-61.

Мешков Н.А. (2016) Клинико-эпидемиологическая оценка влияния факторов риска на развитие болезней системы кровообращения у ликвидаторов последствий Чернобыльской катастрофы. Радиац. риск, 25(1): 94-107.

Митьковская Н.П. (2016) Кардиология и коморбидность. I международный конгресс кардиологов и терапевтов. Капитал Принт, Минск, с. 173-177.

Обрезан А.Г. (2008) Структура сердечно-сосудистых заболеваний у больных сахарным диабетом 2 типа, диабетическая кардиомиопатия как особое состояние миокарда. Вест. СПбГу, 11(2): 47-53.

Поровский Я.В. (2015) Коморбидность во врачебной практике. Сиб. мед. обозр., 4: 5-10.

Старченко Т.Г., Коваль С.М., Юшко К.О. та ін. (2018) Формування порушення ритму серця у хворих на артеріальну гіпертензію з цукровим діабетом 2 типу. Вісн. пробл. біол. мед., 3: 42-46.

Телкова И.Л. (2010) Особенности патологии сердечно-сосудистой системы у ликвидаторов последствий аварии на Чернобыльской АЭС по данным кардиологического стационара. Бюл. сиб. мед., 5: 180-186.

Чесникова А.И., Батюшин М.М., Терентьев В.П. (2016) Артериальная гипертензия и коморбидность: современное состояние проблемы. Арт. гиперт. 22(5): 432-440.

Adams K.F., Schatzkin A., Harris T.B. et al. (2006) Overweight, obesity, and mortality in a large prospective cohort of persons 50 to 71 years old. N. Engl. J. Med., 355(8): 763-778.

Fihn S.D., Gardin J.M. , Abrams J. et al.; American College of Cardiology Foundation; American Heart Association Task Force on Practice Guidelines; American College of Physicians et al. (2012) 2012 ACCF/AHA/ ACP/AATS/PCNA/SCAI/STS Guideline for the diagnosis and management of patients with stable ischemic heart disease: a report of the American College of Cardiology Foundation/American Heart Association Task Force on Practice Guidelines, and the American College of Physicians, American Association for Thoracic Surgery, Preventive Cardiovascular Nurses Association, Society for Cardiovascular Angiography and Interventions, and Society of Thoracic Surgeons. J. Am. Coll. Cardiol., 60(24): e44-e164.
Montalescot G., Sechtem U., Achenbach S. et al. (2013) 2013 ESC guidelines on the management of stable coronary artery disease: the task force on the management of stable coronary artery disease of the European Society of Cardiology. Eur. Heart J., 34: 2949-3003.

Wilkins E., Wilson L., Wickramasinghe K. et al. (2017) European cardiovascular disease statistics 2017. European Heart Network, Brussels, 192 p.

\section{Развитие заболеваний системы кровообращения, сахарного диабета и ожирения у участников ликвидации последствий аварии на ЧАЭС в 30-летний послеаварийный период}

\section{А.Д. Базыка, Д.А. Белый}

Резюме. Определена динамика развития гипертонической болезни (ГБ), ишемической болезни сердца (ИБС), сахарного диабета (СД) 2-го типа и ожирения у участников ликвидации последствий аварии на ЧАЭС (УЛПА) в течение 30-летнего периода наблюдения. Установлено, что после участия в аварийных работах ГБ, ИБС, СД 2-го типа и ожирение у УЛПА развивались в более ранние сроки и в более молодом возрасте по сравнению с контрольной группой (КГ). Подавляющее число УЛПА заболело ГБ в первые 10 лет, лиц КГ- во время 2-го и 3-го десятилетия после аварии. У всех УЛПА признаки ИБС выявлены в первые 20 лет, лиц КГ - в 3-м десятилетии периода наблюдения. У 93,9\% УЛПА развитие ГБ достоверно опережало клинический дебют СД на 25, 7 года, у 66,7\% УЛПА развитие ИБС - на 19,4 года. У 92,0\% лиц КГ эта разница составляла 19,5 года, у 76,0\% - 15,5 года соответственно. ГБ достоверно повышала риск развития СД 2-го типа как у УЛПА, так и у лиц КГ, тогда как ИБС не проявляла такого воздействия. Более половины УЛПА и лиц КГ имели избыточную массу тела или ожирение, когда у них развились ГБ и ИБС. Участие в ликвидации последствий аварии в сочетании с воздействием ионизирующего излучения можно считать вероятным фактором риска ГБ, ИБС и СД 2-го типа.

Ключевые слова: участники ликвидации последствий аварии на ЧАЭС, гипертоническая болезнь, ишемическая болезнь сердца, сахарный диабет.

\section{Development of blood circulation diseases,} diabetes mellitus and obesity in emergency workers during 30 years after the accident at ChNPP

\section{O.D. Bazyka, D.O. Belyi}

Summary. The development of hypertensive heart disease (HHD), coronary heart disease (CHD), diabetes mellitus (DM) type 2 and obesity in emergency workers (EW) was studied in dynamics during the 30year after the accident at the ChNPP. It was revealed that after emergency works HHD, CHD, DM type 2 and obesity in the EW developed earlier and at younger age comparing with non-irradiated persons. The majority of EW came down with HHD during the first 10 years, but non-irradiated persons during the $2 n d$ and $3 r d$ decades after the accident. In all EW CHD was detected during the first 20 years after exposure, but in non-irradiated persons during the 3rd decade of the observation period. In 93.9\% of EW the development of HHD significantly outpaced the clinical debut of DM on 25.7 years, and $66.7 \%$ of EW development CHD on 19.4 years. In 92.0\% of non-exposed patients this difference was $19.5,76.0 \%$ and 15.5 years, respectively. HHD significantly increased the risk of developing DM type 2, both in EW and the non-irradiated control. CHD did not show such effect. More than a half of EW and non-irradiated control had excessive body mass or obesity when $H H D$ and $C H D$ developed. Participation in EW under the exposure of ionizing radiation may be considered as probable risk factor for $H H D, C H D$ and DM type 2 .

Key words: emergency workers of the accident at ChNPP, hypertensive heart disease, coronary heart disease, diabetes mellitus.

\section{Адреса для листування:}

Білий Давид Олександрович

Інститут клінічної радіології ДУ «ННЦРМ НАМН України»,

відділення кардіології відділу терапії радіаційних наслідків

E-mail: dbelyi_2000@yahoo.com

Одержано 03.06.2019 